Sariadi/Jurnal Ekonomi Syariah Teori dan Terapan Vol. 6 No. 3 Maret 2019: 639-657; ANALISIS

IMPLEMENTASI PRINSIP BAGI HASIL DAN RESIKO PADA BPRS KABUPATEN DELI SERDANG DAN BPRS KOTA MEDAN

\title{
ANALISIS IMPLEMENTASI PRINSIP BAGI HASIL DAN RESIKO PADA BPRS KABUPATEN DELI SERDANG DAN BPRS KOTA MEDAN
}

\author{
Sariadi \\ Program Magister Ekonomi Islam-Institut Agama Islam Negeri Sumatera Utara, Medan \\ Email: yogakombih@gmail.com
}

\begin{abstract}
:
This study aims to determine the implementation of the principle of profit sharing and risk in fund raising activities in BPRS Deli Serdang and Medan. This research was conducted using qualitative research methods in two BPRS in Deli Serdang Regencyand BPRS Medan City. Data collection in this study was conducted by interviewing, observing, and literature review. The results of the study show that the collection of funds from the public in the BPRS (Deli Serdang and Medan) is done by wadiah and mudharabah savings and Deposit Mudharabah, but on BPRS Puduarta Insani only applies wadiah savings and Deposit Mudharbah, as well as BPRS Amanah Insan Cita only applies the Wadiah and Deposit funds. Mudharabah. Whereas BPRS Al-Washliyah in collecting funds from the public was carried out with mudharabah savings and Mudharabah deposits. However, BPRS Gebu Prima applies the three contracts, namely wadiah savings and mudharabah savings and mudharbah deposits.
\end{abstract}

Keywords: Implementasi, Bagi Hasil, Risiko, BPRS

\section{PENDAHULUAN}

Perkembangan sistem dan praktik ekonomi syari'ah mulai terlihat marak di tanah air lebih kurang dalam beberapa dekade terakhir. Perkembangan ini tidak terlepas dari alasan pokok keberadaan sistem ekonomi syari'ah, yaitu keinginan masyarakat muslim menjalankan Islam secara kaffah dalam segala aspek kehidupan, sebagaimana dijelaskan dalam surah Al-Baqarah ayat (208) yang artinya sebagai berikut: "Hai orang-orang yang beriman, masuklah kamu kedalam Islam secara kaffah (utuh/menyeluruh). Ayat ini dengan tegas mengingatkan kepada ummat Islam untuk melaksanakan Islam secara kaffah bukan secara parsial, Islam tidak hanya diwujudkan dalam bentuk ritualisme ibadah semata, dan dimarginalkan dari dunia politik, ekonomi, perbankan, asuransi, pasar modal, pembiayaan proyek, transaksi eksporimpor dan lain-lain, apabila hal ini terjadi, maka ummat Islam telah menjauhkan Islam dari kehidupannya.

Muhammad Safi'i Antonio (1999) menyatakan bahwa sangat disayangkan, dewasa ini masih banyak kalangan yang melihat bahwa Islam tidak berurusan dengan bank dan pasar vang, karena yang pertama adalah dunia putih sementara yang kedua adalah dunia hitam, penuh tipu daya dan kelicikan. Indonesia sebenarnya mengenal ekonomi syariah lebih dulu bahkan jauh sebelum sistem kapitalis. Perkembangan ekonomi syari'ah saat ini sangat diwarnai oleh perkembangan perbankan syari'ah. Dalam fenomena meningkatnya kebutuhan masyarakat terhadap keberadaan sistem perbankan yang sesuai dengan prinsip syari'ah mendapat 
Sariadi/Jurnal Ekonomi Syariah Teori dan Terapan Vol. 6 No. 3 Maret 2019: 639-657; ANALISIS IMPLEMENTASI PRINSIP BAGI HASIL DAN RESIKO PADA BPRS KABUPATEN DELI SERDANG DAN BPRS KOTA MEDAN

respon dari pemerintah, yang antara lain dikeluarkannya Undang-Undang No. 7 tahun 1992 tentang perbankan, yang menetapkan bahwa sistem perbankan di Indonesia menganut Dual Banking System, yaitu perbankan konvensional dan perbankan syari'ah. Kemudian UndangUndang tersebut disempurnakan dengan Undang-Undang No.10 tahun 1998, guna memberikan landasan hukum yang lebih jelas bagi operasional perbankan syari'ah.

Hasil penelitian Bank Indonesia (1999) masih terdapat masyarakat yang enggan berhubungan dengan bank sebagai akibat dari diterapkannya sistem bunga yang diyakini sebagai riba yang diharamkan. Oleh karena itu dibutuhkan suatu konsep alternatif sistem perbankan yang dapat menampung tuntutan dan kebutuhan masyarakat, dengan sistim bagi hasil dan risiko (profit and loss sharing), yang mengedepankan prinsip keadilan dan kebersamaan dalam berusaha, baik dalam memperoleh keuntungan maupun dalam menghadapi risiko. Bukti konkrit yang perlu diambil ibroh (pelajaran) ketika bunga diterapkan oleh perbankan konvensional, sehingga bangsa Indonesia mengalami krisis ekonomi dan moneter yang memporakporandakan sendi-sendi kehidupan bangsa, yang pada akhirnya Indonesia sangat terpuruk dalam berbagai sektor kehidupan.

Salah satu sektor yang sangat mencengangkan adalah ketika perbankan konvensional dengan sistim bunganya mengalami kebangkrutan sejak tahun 1997, sekitar 30 bank ditutup atau dilikuidasi dan selanjutnya ada 55 bank masuk dalam kategori pengawasan oleh BPPN. Untuk membantu bank-bank tersebut pemerintah terpaksa membantu dengan mengucurkan bantuan kredit yang dikenal dengan Bantuan Likuiditas Bank Indonesia (BLBI) yang sampai sekarang belum dapat di lunasi oleh kreditornya. Kondisi ini sangat berbeda dengan perbankan yang beroperasi sesuai dengan prinsip Syari'ah, hal ini disebabkan karena Bank syari ah tidak dibebani membayar bunga simpanan nasabah. Bank syari ah hanya membayar bagi hasil yang jumlahnya sesuai dengan nisbah yang disepakati sejak awal dan tingkat keuntungan yang di peroleh bank syari ah. Dengan sistem bagi hasil tersebut, maka jelas bank-bank syari ah selamat dari negative spread.

Perbankan syari'ah adalah salah satu unsur dari sistem keuangan syariah. Maraknya perkembangan perbankan syari'ah juga diakui dengan perkembangan lembaga-lembaga keuangan syariah lainnya dan kegiatan ekonomi yang diidentifikasikan sesuai dengan prinsip syari'ah. Perkembangan lembaga keuangan syariah di luar sektor perbankan yang layak dicatat adalah perkembangan BPRS. BPRS merupakan lembaga keuangan rakyat kecil yang beroperasi berdasarkan sistem syari'ah 
Sariadi/Jurnal Ekonomi Syariah Teori dan Terapan Vol. 6 No. 3 Maret 2019: 639-657; ANALISIS IMPLEMENTASI PRINSIP BAGI HASIL DAN RESIKO PADA BPRS KABUPATEN DELI SERDANG DAN BPRS KOTA MEDAN

Islam. Kegiatan pokok BPRS diarahkan pada usaha produktif, UKM, dan investasi.

Berdirinya BPRS di Indonesia selain didasari oleh tuntutan bermuamalah secara Islam yang merupakan keinginan kuat dari sebagain besar umat Islam di Indonesia, juga sebagai langkah aktif dalam rangka restrukturisasi perekonomian Indonesia yang dituangkan dalam berbagai paket kebijakan keuangan dan moneter. Secara umum, BPRS memiliki fungsi sebagai agen pembangunan yang diharapkan dan mampu mewujudkan pemerataan pelayanan perbankan, pemerataan kesempatan berusaha dan pemerataan pendapatan masyarakat melalui pemberian bantuan kredit serta menghimpun dana dari masyarakat. Di samping itu BPRS juga berfungsi mempersempit ruang gerak para pelepas vang dan rentenir yang sampai saat ini masih sulit untuk diberantas.

Di lihat dari segi kedudukan dan perannya, BPRS memiliki landasan hukum yang kuat, sehingga dapat memberi peran yang lebih maksimal dan memberi daya tawar positif untuk mempercepat pertumbuhan ekonomi nasional. Akan tetapi proses sosialisasi dan pelayanan yang diberikan oleh lembaga ekonomi syari'ah kepada masyarakat dirasakan belum begitu efektif. BPRS merupakan lembaga komersial yang berfungsi sebagai mediator antara masyarakat yang memiliki kelebihan dana dengan yang kekurangan atau yang membutuhkan dana untuk usaha-usaha produktif melalui pembiayaan dengan prinsip bagi hasil atau jual beli, juga menumbuh kembangkan usaha mikro dan usaha kecil dalam menjalankan bisnisnya serta membela kepentingan fakir miskin. BPRS mampu mengurangi angka pengangguran baik yang telibat sebagai karyawan BPRS maupun UKM. Selain itu juga BPRS merupakan salah satu solusi bagi penanganan permasalahan pembiayaan lebih cepat dan mudah.

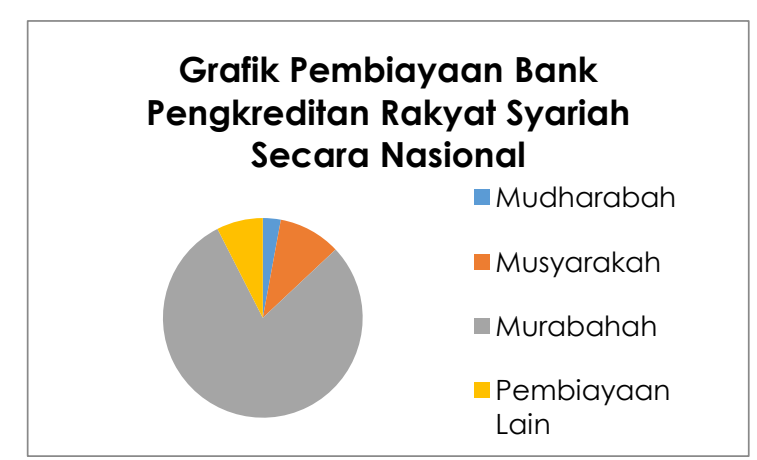

Sumber: DiolahOlehPeneliti, 2013.

\section{Gambar 1.}

\section{Grafik Pembiayaan BPRS Nasional}

Di balik perkembangan Bank Pengkreditan Rakyat Syari'ah yang secara kuantitas semakin berkembang, tetapi dalam pelaksanaanya, prinsip dasar dalam kegiatan BPRS sistem bagi hasil kurang di minati dalam kegiatan pembiayaan Bank Pengkreditan Rakyat Syari'ah. Pembiayaan mudharabah secara nasional pada tahun 2011 sebesar 77,6 milliar atau sebesar 2,9\% dan pembiayaan musyarakah sebesar 263,9 milliar atau sebesar 10,1 \% (persen) bila di bandingkan dengan pembiayaan 
Sariadi/Jurnal Ekonomi Syariah Teori dan Terapan Vol. 6 No. 3 Maret 2019: 639-657; ANALISIS IMPLEMENTASI PRINSIP BAGI HASIL DAN RESIKO PADA BPRS KABUPATEN DELI SERDANG DAN BPRS KOTA MEDAN

murabahah (jual beli) yang sebesar 2,07 triliun atau sebesar $79,5 \%$ (persen), dari total pembiayaan sebesar 2,62 Trilyun (Statistik Perbankan Syariah, 2011).

Profit and loss sharing (bagi hasil dan risiko), pada dasarnya merupakan pembiayaan dengan prinsip kepercayaan dan kesepakatan murni antara kedua belah pihak atau lebih yaitu pemilik modal (investor) dalam hal ini Bank Syari'ah dengan pemilik usaha dan nasabah pengelola usaha.Secara teoritis prinsip bagi hasil dan risiko merupakan inti atau karakteristik utama dari kegiatan perbankan syari'ah. Akan tetapi dalam kegiatan pembiayaan bagi hasil dan risiko produk musyarakah dan mudharabah kurang di minati dalam kegiatan pembiayaan, hal ini bisa dilihat dari data diatas. Hal ini disebabkan oleh karena tingkat risiko pembiayaan mudharabah dan Musyarakah sangat tinggi (hight risk) dan pengembaliannya tidak pasti, padahal bank merupakan lembaga bisnis, lembaga-lembaga intermediasi dimana bank berfungsi sebagai perantara pihak yang kekurangan modal (lack of fund) dan pihak lain yang kelebihan modal (surplus of fund), disamping itu bank juga harus mengembalikan dana nasabah penabung setiap saat. Semestinya bank dengan nasabah harus memahami betul tentang filosofi pembiayaan dengan sistem mudharabah dan Musyarakah, karena Islam memberikan solusi yang adil bagi kedua belah pihak dengan prinsip pertanggung jawaban yang jelas, bukan hanya ingin mendapatkan keuntungan sendiri sementara pihak yang lain mengalami kerugian bahkan sampai pada titik dimana tidak punya apa-apa bahkan secara ekonomi tidak berdaya lagi. Disinilah pentingnya kita mengkaji dan menemukan konsep yang ideal dari prinsip bagi hasil dan risiko (Profit and Loss Sharing) dalam perbankan syari'ah, agar kedua belah pihak baik bank maupun nasabah peminjam dapat menjalankan usaha atau bisnisnya dengan aman tanpa ada kekhawatiran atau ketakutan yang berlebihan, sehingga produk mudharabah dan Musyarakah akan tetap menjadi produk pembiayaan yang utama bagi Bank Syari'ah pada masa yang akan datang.

Berdasarkan uraian di atas, hal inilah yang melatarbelakangi peneliti untuk meneliti lebih jauh tentang permasalahan yang berkaitan dengan prinsip bagi hasil dan risiko (profit and loss sharing) baik itu dari segi penghimpunan dana dan pelaksanaanya dengan kegiatan pembiayaan mudharabah dan Musyarakah dalam Bank Pengkreditan Rakyat Syari'ah, sehingga menarik dan perlu untuk diteliti dengan memfokuskan pada BPRS, dimana hal ini merupakan titik sentral sebagai sasaran dalam penelitian ini. 
Sariadi/Jurnal Ekonomi Syariah Teori dan Terapan Vol. 6 No. 3 Maret 2019: 639-657; ANALISIS IMPLEMENTASI PRINSIP BAGI HASIL DAN RESIKO PADA BPRS KABUPATEN DELI SERDANG DAN BPRS KOTA MEDAN

\section{LANDASAN TEORI DAN PENGEMBANGAN HIPOTESIS}

Islam merupakan pedoman hidup. Tidak seperti di masyarakat barat dimana antara agama dan aktivitas hidup seharihari seperti politik dan ekonomi sengaja dibedakan. Sedangkan Islam merupakan satu-satunya pedoman bagi kehidupan sehari-hari, hal ini termasuk dalam pedoman yang mengatur bagaimana melakukan kegiatan perekonomian. AlQur'an sebagai kitab suci umat Islam bukan saja mengatur masalah yang berkaitan dengan hubungan manusia dengan penciptanya akan tetapi juga mengatur hubungan manusia dengan manusia lainnya dalam berbagai kegiatan sehar-hari salah satunya adalah kegiatan perekonomian. Sarjana Yahudi cC. Torrey dalam bukunya, The Commercial Theological Term in the Koran, menyimpulkan bahwa istilah-istilah ekonomi dan bisnis dalam Al-Quran bukan hanya merupakan kiasan-kiasan ilustratif tetapi merupakan butir-butir doktrin yang paling mendasar dalam bidang ekonomi dan bisnis.

Kara (2005) menjelaskan bahwa dalam bahasa Arab istilah ekonomi diungkapkan dengan kata al-'iqtisad, yang secara bahasa berarti kesederhanaan dan kehematan. Ekonomi adalah pengetahuan tentang peristiwa dan persoalan yang berkaitan dengan upaya manusia secara perseorangan (pribadi), kelompok (keluarga, suku bangsa, organisasi) dalam memenuhi kebutuhan yang tidak terbatas yang dihadapkan pada sumber yang terbatas.

Fikri (dalam Kamal, 1997) mendefinisikan ekonomi Islam adalah kumpulan dari dasar-dasar ilmu ekonomi yang diambil dari Al-Qur'an dan sunnah Rasulullah serta dari tatanan ekonomi yang dibangun diatas dasar-dasar tersebut, sesuai dengan berbagai macam bi'ah (lingkungan) dan setiap zaman. Pada definisi tersebut terdapat dua hal pokok yang menjadi landasan hukum sistem ekonomi Islam yaitu: Al-Qur'an dan sunnah Rasulullah, hukum-hukum yang diambil dari kedua landasan pokok tersebut secara konsep dan prinsip adalah tetap (tidak dapat berubah kapanpun dan dimana saja), akan tetapi pada prakteknya untuk hal-hal dan situasi serta kondisi tertentu bisa saja berlaku marunnah dan ada pula yang bisa mengalami perubahan. Sedangkan Chapra (2001) secara mendalam menjelaskan bahwa ekonomi Islam sebagai cabang ilmu pengetahuan yang membantu mewujudkan kesejahteraan manusia melalui alokasi dan distribusi sumber-sumber daya langka sesuai dengan al-'iqtisad al-syariah atau tujuan ditetapkan syariah, tanpa mengekang kebebasan individu secara berlebihan, menimbulkan ketidakseimbangan makro ekonomi dan ekologi atau melemahkan keluarga dan solodaritas sosial dan jalinan moral dari masyarakat. Ekonomi dalam 
Sariadi/Jurnal Ekonomi Syariah Teori dan Terapan Vol. 6 No. 3 Maret 2019: 639-657; ANALISIS IMPLEMENTASI PRINSIP BAGI HASIL DAN RESIKO PADA BPRS KABUPATEN DELI SERDANG DAN BPRS KOTA MEDAN

pandangannya harus mengaitkan antara persoalan ekonomi dan persoalan sosial kemanusiaan yang menjadi tujuan syariat Islam. Jadi tidak semata-mata pemenuhan kebutuhan material sebagaimana dikemukakan oleh para ekonom kapitalis.

Sistem ekonomi Islam dimaksudkan untuk mengatur kegiatan ekonomi guna mencapai derajat kehidupan yang layak bagi seluruh individu-individu dalam masyarakat. Sistem ekonomi Islam diseluruh kegiatan dan kebiasaan masyarakat bersifat dinamis dan adil dalam pembagian pendapatan dan kekayaan dengan memberikan hak pada setiap individu untuk mendapatkan penghidupan yang layak dan mulia baik di dunia maupun di akhirat nantinya.

Dengan demikian dapat dikatakan bahwa para pemikir ekonomi Islam melihat persoalan ekonomi tidak hanya berkaitan dengan faktor produksi, konsumsi dan distribusi, berupa pengelolaan sumber daya yang ada untuk kepentingan bernilai ekonomis. Akan tetapi, lebih dari itu mereka melihat persoalan ekonomi sangat terkait dengan persoalan moral, ketidakadilan, ketauhidan dan sebagainya. Sehingga para pakar menempatkan individu (manusia) sebagai objek kajian ekonomi dengan konsep mengkaji individu sebagai mahluk sosial, juga menempatkan individu sebagai mahluk yang mempunyai potensi religius. Oleh sebab itu, dalam pemenuhan kebutuhannya, aktivitas ekonomi lainnya, ekonomi Islam menempatkan nilai-nilai Islam sebagai dasar pijakanya. Hal inilah yang membedakan dengan konsep ekonomi barat yang menempatkan kepentingan individu sebagai landasannya. Nilai-nilai Islam tidak hanya berkaitan dengan proses ekonomi tapi juga berkaitan dengan tujuan dari kegiatan ekonomi. Islam menempatkan bahwa tujuan ekonomi tidak hanya kesejahteraan duniawi saja, tetapi juga untuk kepentingan yang lebih utama yaitu kesejahteraan ukhrawi.

Istilah bagi hasil sebenarnya bukan hal baru dalam kegiatan ekonomi di Indonesia. Sistem bagi hasil sudah di kenal sejak dahulu melalui bagi hasil pertanian yang dilakukan oleh penggarap dan pemilik lahan. Bagi hasil sendiri menurut terminologi asing (Inggris) dikenal dengan profit sharing. Menurut terminologi Indonesia Profit sharing adalah bagi keuntungan. Dalam kamus ekonomi diartikan pembagian laba (Muhammad, 2002). Profit secara istilah adalah perbedaan yang timbul ketika total pendapatan (total revenue) suatu perusahaan lebih besar dari biaya total (total cost).

Sistem perekonomian Islam merupakan masalah yang berkaitan dengan pembagian hasil usaha harus ditentukan pada awal terjadinya kontrak kerjasama (akad), yang ditentukan 
Sariadi/Jurnal Ekonomi Syariah Teori dan Terapan Vol. 6 No. 3 Maret 2019: 639-657; ANALISIS IMPLEMENTASI PRINSIP BAGI HASIL DAN RESIKO PADA BPRS KABUPATEN DELI SERDANG DAN BPRS KOTA MEDAN

adalah porsi masing-masing pihak, misalkan 20:80 yang berarti bahwa atas hasil usaha yang diperoleh akan didistribusikan sebesar 20\% bagi pemilik dana (shahibul maal) dan $80 \%$ bagi pengelola dana (mudharib). Bagi Hasil adalah bentuk return (perolehan kembaliannya) dari kontrak investasi, dari waktu ke waktu, tidak pasti dan tidak tetap. Besar-kecilnya perolehan kembali itu bergantung pada hasil usaha yang benar-benar terjadi. Dengan demikian, dapat dikatakan bahwa sistem bagi hasil merupakan salah satu praktik perbankan syari'ah (Karim, 2006). Menurut Karim (2006) bagi hasil terdiri dari dua sistem, yaitu:

a. Profit Sharing adalah bagi hasil yang dihitung dari pendapatan setelah dikurangi biaya pengelolaan dana. Dalam system syari'ah pola ini dapat digunakan untuk keperluan distribusi hasil usaha lembaga keuangan syari'ah.

b. Revenue Sharing adalah bagi hasil yang dihitung dari total pendapatan pengelolaan dana. Dalam system syari' ah pola ini dapat digunakan untuk keperluan distribusi hasil usaha lembaga keuangan syari'ah.

Aplikasi perbankan syari'ah pada umumnya, bank dapat menggunakan sistem profit sharing maupun revenue sharing tergantung kepada kebijakan masing-masing bank untuk memilih salah satu dari sistem yang ada. Bank-bank syari'ah yang ada di Indonesia saat ini semuanya menggunakan perhitungan bagi hasil atas dasar revenue sharing untuk mendistribusikan bagi hasil kepada para pemilik dana (IBI, 2001).

Suatu bank menggunakan sistem profit sharing di mana bagi hasil dihitung dari pendapatan netto setelah dikurangi biaya bank, maka kemungkinan yang akan terjadi adalah bagi hasil yang akan diterima oleh para shahibul maal (pemilik dana) akan semakin kecil, tentunya akan mempunyai dampak yang cukup signifikan apabila ternyata secara umum tingkat suku bunga pasar lebih tinggi. Kondisi ini akan mempengaruhi keinginan masyarakat untuk menginvestasikan dananya pada bank syari'ah yang berdampak menurunnya jumlah dana pihak ketiga secara keseluruhan, tetapi apabila bank tetap ingin mempertahankan sistem profit sharing tersebut dalam perhitungan bagi hasil mereka, maka jalan satu-satunya untuk menghindari resiko-resiko tersebut di atas, dengan cara bank harus mengalokasikan sebagian dari porsi bagi hasil yang mereka terima untuk subsidi terhadap bagi hasil yang akan dibagikan kepada nasabah pemilik dana (IBI, 2001).

Bagi hasil menurut terminologi asing dikenal dengan profit sharing atau pembagian laba. Profit sharing diartikan sebagai distribusi beberapa bagian dari laba pada para pegawai dari suatu perusahaan (Muhammad, 2004). Hal itu 
Sariadi/Jurnal Ekonomi Syariah Teori dan Terapan Vol. 6 No. 3 Maret 2019: 639-657; ANALISIS IMPLEMENTASI PRINSIP BAGI HASIL DAN RESIKO PADA BPRS KABUPATEN DELI SERDANG DAN BPRS KOTA MEDAN

dapat berbentuk suatu bonus uang tunai tahunan yang didasarkan pada laba yang diperoleh pada tahun-tahun sebelumnya, atau dapat berbentuk pembayaran mingguan/bulanan. Mekanisme lembaga keuangan syari'ah pada pendapatan bagi hasil ini berlaku untuk produk penyertaan atau bentuk bisnis korporasi (kerjasama). Pihak-pihak yang terlibat dalam kepentingan bisnis yang disebutkan tadi harus melakukan transparasi dan kemitraan secara baik dan ideal. Sebab semua pengeluaran dan pemasukan rutin yang berkaitan dengan bisnis penyertaan, bukan untuk kepentingan pribadi yang menjalankan proyek (Muhammad, 2004).

Keuntungan yang dibagi hasilkan harus dibagi secara proporsional antara shahibul maal dengan mudharib. Dengan demikian, semua pengeluaran rutin yang berkaitan dengan bisnis mudharabah, dapat dimasukkan ke dalam biaya operasional. Keuntungan bersih harus dibagi antara shahibul maal dan mudharib sesuai dengan proporsi yang disepakati sebelumnya dan secara eksplisit disebutkan dalam perjanjian awal. Tidak ada pembagian laba sampai semua kerugian telah ditutup dan ekuiti shahibul maal telah dibayar kembali. Jika ada pembagian keuntungan sebelum habis masa perjanjian akan dianggap sebagai pembagian keuntungan dimuka (Muhammad, 2004).
Kerja sama para pihak dengan sistem bagi hasil harus dilaksanakan dengan transparan dan adil. Hal ini disebabkan untuk mengetahui tingkat bagi hasil pada periode tertentu itu tidak dapat dijalankan kecuali harus ada laporan keuangan atau pengakuan yang terpercaya. Pada tahap perjanjian kerja sama ini disetujui oleh para pihak, maka semua aspek yang berkaitan dengan usaha harus disepakati dalam kontrak, agar antar pihak dapat saling mengingatkan (Ridwan, 2004). Menurut Adiwarman (2004) terdapat beberapa faktor yang mempengaruhi besarnya bagi hasil di perbankan syari'ah adalah:

a. Referensi Tingkat (margin) Keuntungan

b. Perkiraan tingkat keuntungan bisnis / proyek yang dibiayai.

Menurut Karim (2006) terdapat halhal yang berkaitan dengan nisbah bagi hasil, yaitu:

a. Persentase

Nisbah keuntungan harus didasarkan dalam bentuk persentase antara kedua belah pihak, bukan dinyatakan dalam nilai nominal rupiah tertentu. Nisbah keuntungan itu misalnya 50:50, 70:30, 60:40, atau 99:1. Jadi nisbah keuntungan ditentukan berdasarkan kesepakatan, bukan berdasarkan porsi setoran modal. Nisbah keuntungan tidak boleh dinyatakan dalam bentuk nominal rupiah tertentu, misalnya shahib almaal mendapat Rp 50.000,00 dan mudharib mendapat Rp 50.000,00. 
Sariadi/Jurnal Ekonomi Syariah Teori dan Terapan Vol. 6 No. 3 Maret 2019: 639-657; ANALISIS IMPLEMENTASI PRINSIP BAGI HASIL DAN RESIKO PADA BPRS KABUPATEN DELI SERDANG DAN BPRS KOTA MEDAN

b. Bagi Untung dan Bagi Rugi

Ketentuan diatas itu merupakan konsekuensi logis dari salah satu akad pembiayaan yang menggunakan prinsip bagi hasil, yaitu karakteristik akad mudharabah, yang tergolong ke dalam kontrak investasi (natural uncertainty contracts). Dalam kontrak ini, return dan timing cash flow kita tergantung kepada kinerja sektor riilnya. Bila laba bisnisnya besar, kedua belah pihak mendapat bagian yang besar pula. Bila laba bisnisnya kecil, mereka mendapat bagian yang kecil juga. Filosofi ini hanya dapat berjalan jika nisbah laba ditentukan dalam bentuk persentase, bukan dalam bentuk nominal rupiah tertentu.

Bila dalam akad mudharabah ini mendapatkan kerugian, pembagian kerugian itu bukan didasarkan atas nisbah, tetapi berdasarkan porsi modal masing-masing pihak seperti halnya pada akad musyarakah. Itulah alasan mengapa nisbahnya disebut sebagai nisbah keuntungan, bukan nisbah saja, karena nisbah 50:50, atau 99:1 itu hanya diterapkan bila bisnisnya untung. Bila bisnisnya rugi, kerugiannya itu harus dibagi berdasarkan porsi masing-masing pihak, bukan berdasarkan nisbah. Hal ini karena ada perbedaan kemampuan untuk mengabsorpsi/menanggung kerugian di antara kedua belah pihak. Bila untung, tidak ada masalah untuk menikmati untung. Karena sebesar apa pun keuntungan yang terjadi, kedua belah pihak akan selalu dapat menikmati keuntungan itu. Lain halnya kalau bisnisnya merugi. Kemampuan shahib almaal untuk menanggung kerugian finansial tidak sama dengan kemampuan mudharib. Dengan demikian, karena kerugian dibagi berdasarkan proporsi modal (finansial) shahib al-maal dalam kontrak ini adalah 100\%, maka kerugian (finansial) ditanggung $100 \%$ pula oleh shahib al-maal. Di lain pihak, karena proporsi modal (finansial) mudharib dalam kontrak ini adalah $0 \%$, andaikata terjadi kerugian, mudharib akan menanggung kerugian (finansial) sebesar 0\% pula.

Apabila bisnis rugi, sesungguhnya mudharib akan menanggung kerugian hilangnya kerja, usaha dan waktu yang telah ia curahkan untuk menjalankan bisnis itu. Kedua belah pihak sama-sama menanggung kerugian, tetapi bentuk kerugian yang ditanggung oleh keduanya berbeda, sesuai dengan objek mudharabah yang dikonstribusikannya. Bila yang dikontribusikan adalah vang, resikonya adalah hilangnya vang tersebut. Sedangkan yang dikontribusikan adalah kerja, resikonya adalah hilangnya kerja, usaha dan waktunya, sehingga tidak mendapatkan hasil apapun atas jerih payahnya selama berbisnis.

C. Jaminan

Ketentuan pembagian kerugian bila kerugian yang terjadi hanya murni diakibatkan oleh resiko bisnis (business risk), bukan karena resiko karakter buruk 
Sariadi/Jurnal Ekonomi Syariah Teori dan Terapan Vol. 6 No. 3 Maret 2019: 639-657; ANALISIS IMPLEMENTASI PRINSIP BAGI HASIL DAN RESIKO PADA BPRS KABUPATEN DELI SERDANG DAN BPRS KOTA MEDAN

mudharib (character risk). Bila kerugian terjadi karena karakter buruk, misalnya karena mudharib lalai dan atau melanggar persyaratan-persyaratan kontrak mudharabah, maka shahib almaal tidak perlu menanggung kerugian seperti ini.

Para fuqaha berpendapat bahwa pada prinsipnya tidak perlu dan tidak boleh mensyaratkan agunan sebagai jaminan, sebagaimana dalam akad syirkah lainnya. Jelas hal ini konteksnya adalah business risk. Sedangkan untuk character risk, mudharib pada hakikatnya menjadi wakil dari shahibul maal dalam mengelola dana dengan seizin shahibul maal, sehingga wajib baginya berlaku amanah. Jika mudharib melakukan keteledoran, kelalaian, kecerobohan dalam merawat dan menjaga dana, yaitu melakukan pelanggaran, kesalahan, dan kelewatan dalam perilakunya yang tidak termasuk dalam bisnis mudharabah yang disepakati, atau ia keluar dari ketentuan yang disepakati, mudharib tersebut harus menanggung kerugian sebesar bagian kelalaiannya sebagai sanksi dan tanggungjawabnya. la telah menimbulkan kerugian karena kelalaian dan perilaku zalim karena ia telah memperlakukan harta orang lain yang dipercayakan kepadanya di luar ketentuan yang disepakati. Mudharib tidak pula berhak untuk menentukan sendiri mengambil bagian dari keuntungan tanpa kehadiran atau sepengetahuan shahibul maal sehingga shahibul maal dirugikan. Jelas hal ini konteksnya adalah character risk (Karim, 2006).

Pihak mudharib yang lalai atau menyalahi kontrak ini, maka shahib almaal dibolehkan meminta jaminan tertentu kepada mudharib. Jaminan ini akan disita oleh shahib al-maal jika ternyata timbul kerugian karena mudharib melakukan kesalahan, yakni lalai dan ingkar janji. Kerugian yang timbul disebabkan karena faktor resiko bisnis, jaminan mudharib tidak dapat disita oleh shahib al-maal. Cara penyelesaiannya adalah jika salah satu pihak tidak menunaikan kewajibannya atau jika terjadi perselisihan di antara kedua pihak, maka penyelesaiannya dilakukan melalui Badan Arbitrasi Syari'ah setelah tidak tercapai kesepakatan melalui musyawarah.

d. Menentukan Besarnya Nisbah

Besarnya nisbah ditentukan berdasarkan kesepakatan masing-masing pihak yang berkontrak. Jadi, angka besaran nisbah ini muncul sebagai hasil tawar-menawar antara shahib al-maal dengan mudharib. Dengan demikian, angka nisbah ini bervariasi, bisa 50:50, 60:40, 70:30, 80:20, bahkan 99:1. Namun para ahli fiqih sepakat bahwa nisbah 100:0 tidak diperbolehkan.

Mudharabah adalah perjanjian kesepakatan bersama antara pemilik bank (shahibul maal) dan nasabah 
Sariadi/Jurnal Ekonomi Syariah Teori dan Terapan Vol. 6 No. 3 Maret 2019: 639-657; ANALISIS IMPLEMENTASI PRINSIP BAGI HASIL DAN RESIKO PADA BPRS KABUPATEN DELI SERDANG DAN BPRS KOTA MEDAN

(mudharib) dengan ketentuan pihak bank menyediakan dana dan pihak nasabah mengelola modal tersebut dan keuntungan dibagi menurut nisbah yang di sepakati. Pemilik modal akan menanggung risiko jika terjadi kerugian yang bukan diakibatkan oleh kelalaian pengusaha. Mudharabah ada dua mcam yaitu pertama Mudharabah muthlaqah adalah mudharib diberi kewenangan penuh untuk mengelola modal dan tidak dibatasi baik dalam penentuan tempat usaha, tujuan maupun jenis usaha. Dan kedua Mudharabah Muqayyadah adalah menetapkan syarat tertentu yang harus di patuhi mudharib baik mengenai tempat, tujuan, maupun jenis usaha (Wiroso, 2006).

Dana Mudarabah ini pada hakikat pelaksanaannya hampir menyerupai dana kredit dari pihak pemberi dana (Financier). Pihak Mudarib pada hakekatnya memegang 4 (empat) jabatan fungsionaris, yaitu pertama sebagai Mudarib, yakni yang melakukan darb, perjalanan dan pengelolaan usaha, dan darb ini merupakan saham penyertaan dari padanya. Kedua sebagai wakil yakni manakala berusaha atas nama perkongsian yang dibiayai oleh sahibul mal. Hal ini akan terlihat tampak jelas sekali terutama dalam Mudarabah Muqayyadah (Mudarabah terbatas). Ketiga sebagai Syarik, yakni partner penyerta karena dia berhak untuk menyertai shahibul mal dalam keuntungan berusaha. Keempat sebagai
Pemegang Amanat, yakni dana Mudarabah dari sahibul mal di mana ia dituntut untuk menjaganya dan mengusahakannya dalam investasi sesuai dengan ketentuan-ketentuan yang telah disepakati bersama termasuk mengembalikannya manakala usaha sudah selesai (Hidayat, 2002).

Skema pelaksanaan akad Mudarabah ini bermaksud, dimana pihak bank sebagai Sahibul Mal, memberikan bantuan dana pelaksanaan proyek atau usaha kepada pengusaha kepada nasabah sebagai Mudarib yang memiliki keahlian untuk melaksanakan usaha. Akad yang digunakan adalah akad Mudarabah dengan nisbah yang disepakati secara bersama. Kemudian pihak bank sebagai Mudarib mengembalikan modal dengan pembagian keuntungan dengan nisbah yang telah sepakati tadi secara cicilan.

\section{METODE PENELITIAN}

Penelitian ini menggunakan metode penelitian kualitatif, yang diharapkan dapat ditemukan maknamakna yang tersembunyi di balik permasalahan sebagai obyek yang akan diteliti. Metode kualitatif berusaha memahami persoalan secara keseluruhan (holistik) dan dapat mengungkapkan rahasia dan makna tertentu (Moleong, 2010). Pendekatan kualitatif memusatkan perhatiannya pada prinsip-prinsip umum yang mendasari perwujudan satuansatuan gejala yang ada dalam kehidupan 
Sariadi/Jurnal Ekonomi Syariah Teori dan Terapan Vol. 6 No. 3 Maret 2019: 639-657; ANALISIS IMPLEMENTASI PRINSIP BAGI HASIL DAN RESIKO PADA BPRS KABUPATEN DELI SERDANG DAN BPRS KOTA MEDAN

manusia, atau pola-pola yang dianalisis gejala-gejala sosial budaya dengan menggunakan kebudayaan dari masyarakat yang bersangkutan untuk memperoleh gambaran mengenai polapola yang berlaku (Burhan, 1998). Hadari Nawawi (1996) menyatakan bahwa penelitian kualitatif sebagai suatu konsep keseluruhan (holistik) untuk mengungkap rahasia sesuatu, dilakukan dengan menghimpun data dalam keadaan sewajarnya (natural setting), mempergunakan cara kerja yang sistematik, terarah dan dapat dipertanggung-jawabkan secara kualitatif, sehingga tidak kehilangan sifat ilmiahnya.

Penelitian ini akan dilaksanakan pada dua BPRS Kabupaten Deli Serdang, yaitu BPRS Gebu Prima dan BPRS Kota Medan, yaitu Al-Washliyah, Puduarta Insani, dan Amanah Insan Cita. Pengumpulan data dalam penelitian ini dilakukan dengan cara wawancara, observasi, dan studi kepustakaan. Data dikelompokan menjadi dua jenis, yaitu data primer yang berasal dari sumber data utama, yang berwujud tindakan sosial, kata-kata dari pihak yang terlibat dengan dan/atau di dalam pendirian dan pengelolaan BPRS. Data primer ini akan diperoleh melalui responden tertentu yang di pilih secara purposive. Penentuan responden dilakukan terhadap beberapa responden yang memenuhi kriteria, yaitu: mereka yang memahami dan menguasai permasalahan perbankan syari'ah dan mereka yang sedang terlibat dengan (di dalam) kegiatan pengelolaan perbankan syari'ah.

Data sekunder, yaitu data yang berasal dari bahan-bahan pustaka, yang meliputi dokumen dokumen tertulis, yang bersumber dari peraturan perundangundangan perbankan, maupun Al Qur'an, Hadist, ljma dan Qiyas para Ulama yang merupakan sumber hukum dalam Islam, termasuk didalamnya berbagai keputusan keputusan yang dikeluarkan oleh organisasi kemasyarakatan Islam baik yang berskala Lokal, Nasional, maupun Internasional, hasil hasil penelitian, artikel artikel ilmiah, buku buku (literatur), dokumen dokumen resmi, arsip arsip dan data statistik tentang perkembangan pembiayaan bagi hasil perbankan syariah.

\section{PEMBAHASAN}

Bagi hasil dalam penghimpunan dana pada dasarnya hanya terdapat dalam akad Mudharabah sedangkan pada akad Wadi'ah tidak terdapat bagi hasil hanya berupa bonus yang di berikan secara sukarela oleh bank tanpa di perjanjikan sebelumnya. Pada saat dimana keadaan persaingan usaha yang sangat ketat dan kempetitif bagi perbankan seperti sekarang ini bonus sepertinya merupakan sesuatu yang mutlak hal ini dimaksudkan untuk merangsang nasabah agar menggunakan akad wadi'ah ini. Pada 
Sariadi/Jurnal Ekonomi Syariah Teori dan Terapan Vol. 6 No. 3 Maret 2019: 639-657; ANALISIS IMPLEMENTASI PRINSIP BAGI HASIL DAN RESIKO PADA BPRS KABUPATEN DELI SERDANG DAN BPRS KOTA MEDAN

BPRS Kabupaten Deli Serdang dan Kota Medan penghimpunan dana dari masyarakat dilakukan dengan prinsip tabungan Wadi'ah dan Mudharabah dan Deposito Mudharabah. Dalam kegiatan penghimpunan dana ini nasabah bertindak sebagai shahibul maal (pemilik dana) dan BPRS sebagai mudharib (pengelola). Adapun cara perhitungan bagi hasil adalah dengan Revenue Sharing artinya bagi hasil yang dihitung dari total pendapatan pengelolaan dana tidak dikurangi dengan biaya.

Berdasarkan hasil penelitian, Penghimpunan dana dari masyarakat di BPRS Kabupaten Deli Serdang dan Kota Medan dilakukan dengan tabungan wadiah dan mudharabah, akan tetapi pada BPRS Puduarta Insani hanya menerapkan tabungan wadiah, begitu halnya BPRS Amanah Insan Cita hanya menerapkan tabungan wadiah. Sedangkan BPRS AI-Washliyah dalam penghimpunan dana dari masyarakat dilakukan dengan tabungan mudharabah. Akan tetapi BPRS Gebu Prima menerapkan kedua tabungan tersebut, yaitu tabungan wadiah dan tabungan mudharabah.

Adapun Equivalen Rate Pada masing-masing BPRS Kabupaten Deli Serdang dan Kota Medan berbeda-beda. Equivalen rate tabungan pada BPRS berbeda dengan equivalen rate pada bank konvensional, equivalen rate pada BPRS berubah-ubah setiap bulannya dan tidak ditentukan di awal akad seperti pada bank konvensional, besarnya equivalen rate yang didapat tidak terlepas dari besarnya pendapatan suatu bank. Berbeda halnya dengan bank konvesional dimana bunga sudah ditetapkan diawal akad berdasarkan jumlah tabungan nasabah.

Tabel 1.

\section{Equivalen Rate tabungan pada BPRS}

Kabupaten Deli Serdang dan Kota Medan Bulan September 2013.

\begin{tabular}{ccc}
\hline No & BPRS & Equivalen \\
\hline 1 & Puduartalnsani & 0.1884 \\
2 & AmanahlnsanCita & 0.2033 \\
3 & Gebu Prima & 0.375 \\
4 & Al-washliyah & 0.1667 \\
5 & Bank Konvensional & 0.2083
\end{tabular}

Sumber: Diolah Oleh Peneliti, 2013.

Berdasarkan tabel di atas, dapat diketahui bahwa equivalen rate pada BPRS Puduarta Insani pada bulan September 2013 sebesar 0.1884, equivalen rate pada BPRS Amanah Insan Cita pada bulan September 2013 sebesar 0.2033, equivalen rate pada BPRS Gebu Prima pada bulan September 2013 sebesar 0.3750, equivalen rate pada BPRS Al-Washliyah pada bulan September 2013 sebesar 0.1667 dan equivalen rate pada Bank Konvensional pada bulan September 2013 sebesar 0.2083. Penjelasan di atas menjelaskan bahwa ada perbedaan antara equivalen rate pada BPRS dan 
Sariadi/Jurnal Ekonomi Syariah Teori dan Terapan Vol. 6 No. 3 Maret 2019: 639-657; ANALISIS IMPLEMENTASI PRINSIP BAGI HASIL DAN RESIKO PADA BPRS KABUPATEN DELI SERDANG DAN BPRS KOTA MEDAN

Bank Konvensional dan equivalen rate BPRS lebih besar dari pada equivalen rate pada bank konvensional pada bulan Septembar 2013. Sehingga dapat disimpulkan Bahwa keuntungan yang didapat Nasabah Pada BPRS lebih Besar dibandingkan keuntungan yang diperoleh nasabah pada Bank Konvensional.

Deposito mudharabah pada BPRS Kabupaten Deli Serdang dan Kota Medan berupa Simpanan berjangka dengan akad bagi hasil dalam mata vang rupiah yang penarikannya hanya dapat dilakukan sesuai dengan jangka waktu yang telah disepakati. Deposito yang diperpanjang setelah jatuh tempo akan diberlakukan sama dengan baru, tetapi bila pada saat akad telah dicantumkam perpanjangan otomatis tidak perlu diperbarui akad baru. Deposito ini dikelola dengan prinsip mudharabah dan mempunyai beberapa pilihan jangka waktu investasi, yaitu terdiri dari 1 bulan, 3 bulan, 6 bulan dan 12 bulan. Suatu kendala bagi BPRS pada deposito mudharabah ini, apabila nasabah mengambil dana investasinya tidak tepat waktunya atau disebut dengan sebelum jatuh tempo.

Nisbah bagi hasil antara Bank (mudharib) dan Nasabah (shahibul mal) bervariasi. Makin panjang jangka waktu investasi nasabah, maka nisbah yang diberikan lebih tinggi. Hal ini dimaksudkan agar menarik nasabah untuk melakukan investasi dalam jangka yang lebih panjang, sehingga memberi keleluasaan pada bank untuk menginvestasikannya pula. Nisbah bagi hasil diberikan oleh bank setiap bulan sesuai tanggal nasabah menyerahkan deposito pada saat permulaan.

Kegiatan bank setelah menghimpun dana dari masyarakat dalam bentuk berbagai simpanan adalah menyalurkan kembali dana tersebut kepada masyarakat yang memerlukannya. Secara umum penyaluran dana dalam perbankan yang menggunakan sistem konvensional adalah pemberian kredit. Sedangkan dalam perbankan syariah penyaluran dana dilakukan dengan pembiayaan. Akad bagi hasil pada BPRS Kabupaten Deli Serdang dan Kota Medan adalah mudharabah dan Musyarakah. Berikut data realisasi pembiayaan berdasarkan akad pada tahun 2012 pada masingmasing BPRS

Tabel 2.

Data Realisasi Pembiayaan Berdasarkan Akad Tahun 2012

BPRS AI-Washliyah

\begin{tabular}{clcc}
\hline No & \multicolumn{1}{c}{ Akad } & $\begin{array}{c}\text { Jumlah } \\
\text { Nasabah }\end{array}$ & $\begin{array}{c}\text { Persenta } \\
\text { se }\end{array}$ \\
\hline 1 & Murabahah & 399 & $82.31 \%$ \\
2 & Mudharabah & 31 & $1.82 \%$ \\
3 & ljarah Multi & 33 & $15.87 \%$ \\
& & \\
& jasa & & \\
\hline \multicolumn{2}{l}{ Total } & 463 & $100.00 \%$
\end{tabular}

Sumber: Diolah Oleh Peneliti, 2013. 
Sariadi/Jurnal Ekonomi Syariah Teori dan Terapan Vol. 6 No. 3 Maret 2019: 639-657; ANALISIS IMPLEMENTASI PRINSIP BAGI HASIL DAN RESIKO PADA BPRS KABUPATEN DELI SERDANG DAN BPRS KOTA MEDAN

Tabel diatas, menjelaskan bahwa selama tahun 2012 BPRS Al-Washliyah merealisasikan akad Murabahah dengan persentase 82.31 dengan jumlah nasabah sebanyak 399, pada akad Mudharabah BPRS Al-Washliyah merealisasikannya dengan persentase 1.82 dengan jumlah nasabah sebanyak 31, dan pada akad ljarah Multijasa BPRS Al-Washliyah merealisasikan pada persentase 15.87 dengan jumlah nasabah sebanyak 33 .

Tabel 3.

Data Realisasi Pembiayaan Berdasarkan

AkadTahun 2012

BPRS Amanah Insan Cita

\begin{tabular}{|c|c|c|c|}
\hline No & Akad & $\begin{array}{c}\text { Jumlah } \\
\text { Nasaba } \\
\text { h }\end{array}$ & $\begin{array}{c}\text { Persentas } \\
\text { e }\end{array}$ \\
\hline 1 & Murabahah & 203 & $93 \%$ \\
\hline 2 & $\begin{array}{l}\text { Mudharaba } \\
\mathrm{h}\end{array}$ & 11 & $4 \%$ \\
\hline 3 & $\begin{array}{l}\text { ljarahMultija } \\
\text { sa }\end{array}$ & 5 & $3 \%$ \\
\hline & Total & 219 & $100.00 \%$ \\
\hline
\end{tabular}

Sumber: Diolah Oleh Peneliti, 2013.

Pada tahun 2012 BPRS Amanah Insan Cita merealisasikan akad Murabahah dengan persentase 93 dan jumlah nasabah sebanyak 203, pada akad Mudharabah BPRS Amanah Insan Cita merealisasikan dengan persentase 4 dan jumlah nasabah sebanyak 11, dan pada akad ljarah Multijasa BPRS Amanah Insan Cita merealisasikan akad tersebut dengan persentase 3 dengan jumlah nasabah sebanyak 5 .
Tabel 4.

Data Realisasi Pembiayaan Berdasarkan

AkadTahun 2012

BPRS Pudu arta Insani

\begin{tabular}{cccc}
\hline No & Akad & $\begin{array}{c}\text { Jumlah } \\
\text { Nasabah }\end{array}$ & $\begin{array}{c}\text { Persenta } \\
\text { se }\end{array}$ \\
\hline 1 & $\begin{array}{l}\text { Murabaha } \\
\text { h }\end{array}$ & 631 & $99.29 \%$ \\
2 & $\begin{array}{l}\text { Mudharab } \\
\text { ah }\end{array}$ & 1 & $0.12 \%$ \\
3 & $\begin{array}{l}\text { ljarahMultij } \\
\text { asa }\end{array}$ & 5 & $0.41 \%$ \\
\hline & Total & 637 & $100.00 \%$
\end{tabular}

Sumber: Diolah Oleh Peneliti, 2013.

Pada tahun 2012 BPRS Puduarta Insani merealisasikan akad Murabahah dengan persentase 99.29 dan jumlah nasabah sebanyak 631, pada akad Mudharabah BPRS Puduarta Insani merealisasikan dengan persentase 0.12 dan jumlah nasabah 1, dan pada akad Ijarah Multijasa BPRS Puduarta Insani merealisasikan akad tersebut dengan persentase 0.41 dengan jumlah nasabah sebanyak 5 .

Tabel 5.

Data Realisasi Pembiayaan Berdasarkan

Akad Tahun 2012

BPRS Gebu Prima

\begin{tabular}{cccc}
\hline No & Akad & $\begin{array}{c}\text { JumlahNasa } \\
\text { bah }\end{array}$ & $\begin{array}{c}\text { Persenta } \\
\text { se }\end{array}$ \\
\hline 1 & $\begin{array}{l}\text { Murabaha } \\
\mathrm{h}\end{array}$ & 897 & $99.19 \%$ \\
2 & $\begin{array}{l}\text { Mudharab } \\
\text { ah }\end{array}$ & - & - \\
3 & ljarahMultij & 20 & $0.81 \%$ \\
\hline
\end{tabular}


Sariadi/Jurnal Ekonomi Syariah Teori dan Terapan Vol. 6 No. 3 Maret 2019: 639-657; ANALISIS IMPLEMENTASI PRINSIP BAGI HASIL DAN RESIKO PADA BPRS KABUPATEN DELI SERDANG DAN BPRS KOTA MEDAN

\begin{tabular}{lll} 
asa & & \\
\hline Total & 917 & $100.00 \%$
\end{tabular}

Sumber: Diolah Oleh Peneliti, 2013.

Pada tahun 2012 BPRS Gebu Prima merealisasikan akad Murabahah dengan persentase 99.19 dan jumlah nasabah sebanyak 897, pada akad Mudharabah pada BPRS Gebu Prima tidak merealisasikan akad tersebut dan pada akad ljarah Multijasa BPRS Gebu Prima merealisasikan akad tersebut dengan persentase 0.81 dengan jumlah nasabah sebanyak 20.Secara teoritis prinsip bagi hasil dan risiko merupakan inti atau karakteristik utama dari kegiatan perbankan syari'ah. Akan tetapi dalam kegiatan pembiayaan bagi hasil dan risiko produk musyarakah dan mudharabah masih belum mencapai target yang diinginkan oleh BPRS seperti akad pembiayaan lainnya. Hal ini bisa dilihat dari tabel-tabel diatas, dimana pada BPRS Al-Washliyah merealisasikan akad Mudharabah dengan persentase 1.82 dengan jumlah nasabah 31 lebih kecil dibandingkan dengan pembiayaan murahabah dengan persentase 82.31 dengan jumlah nasabah 399, begitu juga Pada BPRS Amanah Insan Cita dimana akad mudharbah terealisasikan dengan persentase 4\% dengan jumlah nasabah 11 lebih kecil dibandingkan akad murabahah yang persentasenya sangat tinggi 93\% dengan jumlah nasabah 203, begitu juga pada BPRS Puduarta Insani, dimana akad mudharabah terealisasikan dengan persentase $0.12 \%$ lebih kecil dibandingkan dengan akad murabahah dengan persentase $99.29 \%$. sedangkan pada BPRS Gebu Prima tidak merealisasikan akad Mudahrabah.

Berdasarkan hasil penelitian yang dilakukan oleh peneliti pada BPRS Kabupaten Deli Serdang dan Kota Medan ditemukan beberapa hal yang berkaitan dengan permasalahan yang diangkat dalam penelitian ini. Beberapa faktor yang menjadi kendala operasional BPRS dalam implementasi prinsip Bagi Hasil dan Risiko, yaituPertama, nasabah tidak memiliki pembukuan yang sesuai standar, sehingga menyulitkan BPRS dalam menentukan porsi bagi hasilnya.Kedua, penentuan kolektibilitas, BPRS sulit menentukan apakah nasabah tersebut pada tahapan lancar atau tidak lancar karna nasabah selalu menyembunyikan apa yang didapatnya.Ketiga, tingkat kejujuran nasabah sangat rendah dalam hal perkembangan usahanya, nasabah tidak melaporkan usahanya ketika mendapat keuntungan dan apabila rugi melaporkan usahanya ke Bank.Keempat, pendapatan nasabah tiap bulan tidak dilaporkan kepada Bank sehingga sulit bagi bank untuk mengetahui pendapatan pada proyek tersebut.

\section{SIMPULAN}

Penghimpunan dana dari masyarakat di BPRS Kabupaten Deli Serdang dan Kota Medan dilakukan dengan tabungan wadiah dan 
Sariadi/Jurnal Ekonomi Syariah Teori dan Terapan Vol. 6 No. 3 Maret 2019: 639-657; ANALISIS IMPLEMENTASI PRINSIP BAGI HASIL DAN RESIKO PADA BPRS KABUPATEN DELI SERDANG DAN BPRS KOTA MEDAN

mudharabah serta Deposito Mudharabah, akan tetapi pada BPRS Puduarta Insani hanya menerapkan tabungan wadiah dan Deposito Mudharbah, begitu halnya BPRS Amanah Insan Cita hanya menerapkan tabunngan wadiah dan Deposito Mudharabah. Sedangkan BPRS Al-Washliyah dalam penghimpunan dana dari masyarakat dilakukan dengan tabungan mudharabah dan Deposito Mudharabah. Akan tetapi BPRS Gebu Prima menerapkan ketiga akad tersebut, yaitu tabungan wadiah dan tabungan mudharabah serta deposito mudharbah. Adapun cara perhitungan bagi hasil berbeda pada masing-masing BPRS, BPRS Puduarta Insani, BPRS Gebu Prima dan BPRS Amanah Insan Cita menggunakan Revenue Sharing artinya bagi hasil yang dihitung dari total pendapatan pengelolaan dana tidak dikurangi dengan biaya, sedangkan pada BPRS AlWashliyah dalam perhitungan bagi hasilnya menggunakan Profit Sharing artinya pendapatan yang didistribusikan kepada nasabah dikurangi dengan biaya-biaya. Pada tabungan dan deposito bank syariah tidak menetapkan bunga pada awal akad akan tetapi bank menetapkan nisbah bagi hasil, berbeda halnya dengan bank konvensional, dimana bunga sudah ditetapkan pada awal akad.

$$
\text { Kegiatan bank setelah }
$$
menghimpun dana dari masyarakat dalam bentuk berbagai simpanan adalah menyalurkan kembali dana tersebut kepada masyarakat yang memerlukannya. Akad bagi hasil pada BPRS Kabupaten Deli Serdang dan Kota Medan adalah mudharabah dan Musyarakah. Pada akad bagi hasil yaitu akad mudharbah dan musyarakah belum terealisasi dengan maksimal, pada BPRS Puduarta Insani $0.23 \%$ lebih besar dari pada akad Murabahah $99.61 \%$, pada BPRS Amanah Insan Cita akad mudharbah $4 \%$ sedangkan akad murabahah 93\%, pada BPRS Al-Washliyah akad mudharabah $1.82 \%$ lebih besar dibandingkan akad murabahah $82.31 \%$ dan BPRS Gebu Prima akad Mudharbah 99.19\% lebih besar dibandingkan akad murabahah $0.81 \%$. Perhitungan bagi hasil pada akad bagi hasil menggunakan tersebut dengan mengunakan profit and loss sharing.

Bank Pembiayaan Rakyat Syariah belum mengimplementasikan akad musyarakah, dikarnakan besarnya resiko yang di hadapi oleh BPRS dan dikarnakan tidak adanya nasabah yang memenuhi persyaratan untuk melakukan akad musyarakah tersebut serta masih kurangnya kejujuran pada nasabah dalam hal perkembangan usahanya. Pada Bank syariah keuntungan didapat oleh bank dan nasabah sesuai pada nisbah yang telah disepakati sebelumnya, besar kecilnya bagi hasil yang didapat tergantung pada besar kecilnya nisbah yang disepakati dan tergantung pada 
Sariadi/Jurnal Ekonomi Syariah Teori dan Terapan Vol. 6 No. 3 Maret 2019: 639-657; ANALISIS IMPLEMENTASI PRINSIP BAGI HASIL DAN RESIKO PADA BPRS KABUPATEN DELI SERDANG DAN BPRS KOTA MEDAN

penghasilan proyek yang dikelola. BPRS Kabupaten Deli Serdang dan Kota Medan menghadapi beberapa faktor yang menjadi kendala operasional BPRS dalam implementasi prinsip Bagi Hasil dan Risiko, yaitu:

a. Nasabah tidak memiliki pembukuan yang sesuai standar, sehingga menyulitkan BPRS dalam menentukan porsi bagi hasilnya.

b. Penentuan kolektibilitas, BPRS sulit menentukan apakah nasabah tersebut pada tahapan lancar atau tidak lancar karena nasabah selalu menyembunyikan apa yang didapatnya.

c. Pendapatan nasabah tiap bulan tidak dilaporkan kepada Bank sehingga sulit bagi bank untuk mengetahui pendapatan pada proyektersebut.

d. Tingkat kejujuran nasabah sangat rendah dalam hal perkembangan usahanya, nasabah tidak melaporkan usahanya ketika mendapat keuntungan dan apabila rugi melaporkan usahanya ke Bank.

\section{DAFTAR PUSTAKA}

Chapra, M. U. (2001). The Future of Economic: An Islamic Perspective. Diterjemahkan oleh Amdiar Amir dkk. Landscape Baru Perekonomian Masa Depan. Jakarta: SEBI.

Christopher, P., \& Bryan, L. (1994). Kamus Lengkap Ekonomi. Jakarta: PT. Gelora Aksara Pratama Erlangga.
Hidayat, A., \& Malian, S. (2002). Lembagalembaga Kevangan Umat Kontemporer. Yogyakarta: UII Press. Kamal, M. (1997). Wawasan Islam Dan Ekonomi: Sebuah Bunga Rampai. Jakarta: Lembaga Penerbit Fakultas Ekonomi Universitas Indonesia.

Kara, M. H. (2005). Bank Syariah Di Indonesia: Analisis Kebijakan Pemerintah Indonesia Terhadap Perbankan Syariah. Yogyakarta: UII Press.

Karim, A. A., \& Islam, B. (2006). Analisis Fiqh dan Keuangan. Jakarta: PT. RajaGrafindo Persada.

Moleong, J. Lexy.(2010). Metodologi Penelitian Kualitatif. Edisi Revisi. Cetakan ke-28. Bandung: Remaja Rosdakarya.

Muhammad. (2002). Manajemen Bank Syari'ah. Yogyakarta: UPP AMP YKPN.

Muhammad. (2001). Tehnik Perhitungan Bagi Hasil di Bank Syariah. Yogyakarta: UII Press.

Muhammad, Ridwan. (2004). Manajemen Baitul Maal Wat Tamwil (BMT). Yogyakarta: UII Press.

Sahatah, H. (2004). Bangunan Ekonomi yang Berkeadilan Teori, Pratek dan Realitas Ekonomi Islam. Yogykarta: Magistra Insania Press.

Siddiqie. (1986). Kemitraan Usaha dan Bagi Hasil dalam Hukum Islam. 
Sariadi/Jurnal Ekonomi Syariah Teori dan Terapan Vol. 6 No. 3 Maret 2019: 639-657; ANALISIS IMPLEMENTASI PRINSIP BAGI HASIL DAN RESIKO PADA BPRS KABUPATEN DELI SERDANG DAN BPRS KOTA MEDAN

Terjemahan Fakhriyah Mumtihani. Jakarta: Dana Bhakri Prima Yasa.

Tim Pengembangan Perbankan Syari'ah

IBI. (2001). Konsep, Produk dan Implementasi Operasional Bank Syari'ah. Jakarta: Djambatan.
Torrey, C. C. (1892). CommercialTheological Terms In The Koran. Brill. Wiroso. (2005). PenghimpunanDana dan Distribusi Hasil Usaha BPRS Syari'ah. Jakarta: Grasindo. 